\title{
Replacing dietary fish oil by vegetable oils has little effect on lipogenesis, lipid transport and tissue lipid uptake in rainbow trout (Oncorhynchus mykiss)
}

\author{
Nadège Richard, Sadasivam Kaushik, Laurence Larroquet, Stéphane Panserat and Geneviève Corraze* \\ UMR Nutrition Aquaculture Génomique, INRA Pôle Hydrobiologie, 64310 Saint Pée-sur-Nivelle, France
}

(Received 14 October 2005 - Revised 23 March 2006 - Accepted 24 March 2006)

\begin{abstract}
In order to investigate the effects of dietary lipid sources on mechanisms involved in lipid deposition, two groups of rainbow trout were fed from first-feeding to the commercial size of $1 \mathrm{~kg}$ (for 62 weeks) with two diets differing only by lipid source: $100 \%$ fish oil or $100 \%$ blend of vegetable oils (55\% rapeseed oil, $30 \%$ palm oil, $15 \%$ linseed oil). The activities and levels of gene expression of lipogenic enzymes (fatty acid synthetase, glucose-6-phosphate dehydrogenase and malic enzyme) in liver and of lipoprotein lipase in perivisceral adipose tissue, white muscle and liver were determined. Transport of lipid was studied by determining lipid composition of plasma and lipoprotein classes. We also examined the clearance of LDL by assaying the level of LDL receptor gene expression in several tissues. Total replacement of dietary fish oil by the blend of vegetable oils did not affect growth of rainbow trout and did not modify muscle lipid content. Hepatic lipogenesis and lipid uptake in perivisceral adipose tissue, white muscle and liver were also not modified by dietary treatments. Diets containing the blend of vegetable oils induced a decrease in plasma cholesterol and LDL. In trout fed the vegetable oils diet, expression of LDL receptor gene in the liver was down-regulated.
\end{abstract}

Lipid transport: Lipogenesis: Rainbow trout: Vegetable oils

Fish meal and fish oil are the main raw materials used in the formulation of fish feeds. Due to the expansion of aquaculture, marine fisheries will not be able to sustain the needs of aquaculture in the not too distant future. The global demand for fishmeal for aquafeeds may exceed total available supplies around the year 2020 and for fish oil well before 2010 (New \& Wijkstroem, 2002). Thus, alternatives to the use of marine materials in fish feeds must be found. Several studies have investigated the replacement of fish oil by vegetable oils in fish feed. Partial replacement of fish oils by vegetable oils such as rapeseed, soyabean, linseed or palm oils in fish feeds has no negative impacts on growth and survival of Atlantic salmon (Rosenlund et al. 2001), brook char (Guillou et al. 1995), gilthead sea bream and European seabass (Izquierdo et al. 2003) and rainbow trout (Greene \& Selivonchick, 1990; Caballero et al. 2002). Fatty acid composition of fish lipids generally reflects the fatty acid profile of the diets (Watanabe, 1982). Vegetable oils contain higher levels of saturated and $n$-6 PUFA than fish oil which is richer in $n-3$ PUFA, mainly EPA and docosahexaenoic acid (DHA), and in long-chain MUFA. Lipid deposition in fish tissues involves several metabolic processes: lipogenesis, lipid transport by lipoproteins, tissue lipid uptake (mediated by lipoprotein lipase (LPL)) and storage of lipids (Sheridan, 1988; Tocher, 2003). The main fat deposition sites in salmonids are perivisceral adipose tissue and white muscle (Corraze \& Kaushik, 1999).
In higher vertebrates, many studies have shown that changes in dietary fatty acid composition can induce modification of hepatic lipogenesis (Blake \& Clarke, 1990; Clarke et al. 1990, Salati \& Amir-Ahmady, 2001), lipid transport in blood (Grundy \& Denke, 1990; Fernandez \& West, 2005) and tissue lipid uptake (Montalto \& Bensadoun, 1993; Raclot et al. 1997). In rainbow trout, little information is available concerning how dietary fatty acids influence these processes.

Some studies have shown that activities of hepatic lipogenic enzymes such as fatty acid synthetase (FAS), the main lipogenic enzyme which produces fatty acid, and also glucose-6phosphate dehydrogenase (G6PD) and malic enzyme (ME), which are the purveyors of NADPH, essential for FAS activity, are not modified by partial or total replacement of fish oil by rapeseed oil in Atlantic salmon (Torstensen et al. 2004) or by soyabean or linseed oils in turbot (Regost et al. 2003). PUFA such as EPA or DHA and a high level of linolenic acid inhibit activities of FAS and G6PD in rainbow trout hepatocyte cultures (Alvarez et al. 2000). It was reported that PUFA inhibit expression of G6PD gene by a post-transcriptional mechanism in liver of mice and in rat hepatocytes in vitro (Stabile et al. 1996, 1998). Dietary PUFA decreased the hepatic abundance of FAS mRNA in rats by an inhibition of FAS transcription (Blake \& Clarke, 1990; Clarke et al. 1990). In fish, regulation of lipogenic gene expression by dietary fatty acids has not yet been studied. 
Other important processes involved in lipid deposition are lipid transport and fatty acid uptake in tissues. In fish, transport of endogenous and dietary lipids to peripheral tissues is mediated by lipoproteins, of which the basic molecular organization and role in lipid metabolism are similar to those of mammals (Sheridan, 1988; Babin \& Vernier 1989; Tocher, 2003). Fatty acid composition of dietary lipids affects lipid composition of plasma and plasma lipoproteins in mammals (Jeffery et al. 1996; Temme et al. 1997; Salter et al. 1998; Chang et al. 2004) and in Atlantic salmon (Lie et al. 1993; Torstensen et al. 2000, 2004). In mammals, total cholesterol in plasma and LDL are increased by saturated fatty acids and decreased by PUFA (Grundy \& Denke, 1990). In Atlantic salmon, replacement of fish oil (rich in $n-3$ PUFA) by rapeseed oil (rich in oleic acid and $n$-6 PUFA) led to changes in fatty acid composition of plasma lipoproteins but had no marked effect on their relative lipid class composition (Torstensen et al. 2004). Clearance of LDL from the plasma is mediated by the LDL receptors (LDL-R; Tocher, 2003). Activity and expression of LDL-R are modulated by fatty acids. In mammals, saturated fatty acids tend to decrease LDL-R activity, protein and mRNA abundance while oleic acid and PUFA increase them (Dietschy, 1998; Fernandez \& West, 2005).

Uptake of fatty acids by tissues is mediated by LPL. LPL hydrolyses triacylglycerols of triacylglycerol-rich lipoproteins (chylomicrons and VLDL) and generates fatty acids that are taken up by tissues. Dietary fish oil increases LPL activity in soleus muscle of rat (Baltzell et al. 1991), LPL mRNA in epididymal adipose tissue of rat (Murphy et al. 1993) and post-heparin LPL activity in man (Zampelas et al. 1994). An in vitro study reported that linoleic acid and EPA but not oleic acid lowered the mRNA level, synthesis and level of secretion of LPL in chick adipocytes (Montalto \& Bensadoun, 1993). Raclot et al. (1997) reported that in rat, $n-3$ PUFA, mainly DHA, lowered the level of LPL mRNA in retroperitoneal but not in subcutaneous adipose tissue. In fish, little information is available on the regulation of LPL by the nutritional status. Nevertheless, studies in red sea bream (Pagrus major) indicated that dietary fatty acids regulate, in a tissue-specific fashion, LPL gene expression in liver and visceral adipose tissue (Liang et al. 2002a,b).

The objective of the present study was to investigate the impacts of dietary lipid sources on mechanisms involved in lipid deposition in rainbow trout using biochemical and molecular tools. We determined activities and levels of gene expression of lipogenic enzymes (FAS, G6PD and ME) in liver, and of LPL in several tissues (perivisceral adipose tissue, white muscle and liver). We also examined the transport of lipid by determining the lipid composition of plasma and lipoprotein classes. The clearance of LDL was assessed by measuring the level of gene expression of LDL-R in several tissues (liver, white muscle and perivisceral adipose tissue).

\section{Materials and methods}

Fish and diets

Triploid female rainbow trout (Oncorhynchus mykiss) fry, having an initial body weight of $0.12 \mathrm{~g}$, were reared in the
INRA experimental fish farm (Donzacq, Landes, France) from April 2002 to June 2003, at a constant water temperature of $17 \pm 1{ }^{\circ} \mathrm{C}$ and natural photoperiod. Fish were randomly distributed into eight groups of 300 fish each. Every 3 weeks fish were group weighed and counted to follow growth and feed intake. After 28 weeks, groups of rainbow trout were split in order to obtain six groups of 100 fish, due to the capacity of the tanks. Fish were fed from first-feeding to the commercial size of $1 \mathrm{~kg}(62$ weeks of age) with two isonitrogenous, isolipidic and isoenergetic diets, differing only by lipid source (Table 1). The two diets were: (1) diet FO100: $100 \%$ capelin oil and (2) VO100: $100 \%$ vegetable oil blend (55\% rapeseed, $30 \%$ palm, $15 \%$ linseed) (Table 1 ). The composition of the blend of vegetable oils was chosen in order to provide a level of the different fatty acid classes close to that of fish oil. The diets were produced by Nutreco Aquaculture Research Centre, Norway. Each diet was distributed by hand to visual satiation, $6 \mathrm{~d}$ over $7 \mathrm{~d}$ and feed consumption was recorded every week. The two experimental diets were fed along the entire life cycle, with changes in lipid content and pellet size according to fish size. Starter diets $(0.5,1$, $1.3,1.7$ and $2.2 \mathrm{~mm}$ ) contained $52 \%$ protein, $24 \%$ lipid $(\% \mathrm{DM})$ and the next diets $(3,5$ and $7 \mathrm{~mm})$ contained $50 \%$ protein and $30 \%$ lipid (Table 1). Table 2 presents the fatty acid composition of the diets. The highest level of n-3 PUFA, mostly DHA and EPA, was noticed in diet FO100 which was also rich in 14:0 and MUFA (around $50 \%$ ), mainly $16: 1,20: 1,22: 1$. Diet VO100 was characterized by high levels of MUFA (mainly 18:1n-9), PUFA $n-6$ and contained the highest percentage of $16: 0$ and $18: 3 n-3$.

Table 1. Ingredient composition ( $\mathrm{g} / \mathrm{kg}$ feed) ${ }^{\star}$ and proximate composition of representative diets used (pellet sizes 1.7 and $7 \mathrm{~mm}$ )

\begin{tabular}{|c|c|c|c|c|}
\hline & \multicolumn{2}{|c|}{ Diet F0100 } & \multicolumn{2}{|c|}{ Diet V0100 } \\
\hline & $1.7 \mathrm{~mm}$ & $7 \mathrm{~mm}$ & $1.7 \mathrm{~mm}$ & $7 \mathrm{~mm}$ \\
\hline \multicolumn{5}{|l|}{ Ingredient composition } \\
\hline Fish meal† & $672 \cdot 2$ & $466 \cdot 9$ & $672 \cdot 2$ & $466 \cdot 9$ \\
\hline Maize gluten $\ddagger$ & 0 & $135 \cdot 2$ & 0 & $135 \cdot 2$ \\
\hline Soyabean meal§ & 0 & $100 \cdot 0$ & 0 & $100 \cdot 0$ \\
\hline Wheat\| & $164 \cdot 0$ & $46 \cdot 1$ & $164 \cdot 0$ & $46 \cdot 1$ \\
\hline Capelin oilף & $138 \cdot 8$ & $226 \cdot 8$ & 0 & 0 \\
\hline Rapeseed oil ${ }^{\star \star}$ & 0 & 0 & $76 \cdot 3$ & $124 \cdot 7$ \\
\hline Palm oil†† & 0 & 0 & $41 \cdot 7$ & $68 \cdot 1$ \\
\hline Linseed oilł‡ & 0 & 0 & $20 \cdot 8$ & $34 \cdot 0$ \\
\hline Premixes§§ & $25 \cdot 0$ & $25 \cdot 0$ & $25 \cdot 0$ & $25 \cdot 0$ \\
\hline \multicolumn{5}{|c|}{ Proximate composition } \\
\hline DM (\%) & $94 \cdot 1$ & $92 \cdot 2$ & $94 \cdot 2$ & 92.5 \\
\hline Protein (\% DM) & $52 \cdot 4$ & 50.9 & 52.9 & $51 \cdot 3$ \\
\hline Lipids (\% DM) & $23 \cdot 3$ & $29 \cdot 7$ & $23 \cdot 8$ & $29 \cdot 5$ \\
\hline Energy (kJ/g DM) & $23 \cdot 7$ & $26 \cdot 4$ & 23.5 & $26 \cdot 1$ \\
\hline
\end{tabular}

${ }^{*}$ All diets were produced at Nutreco Technology Centre, Norway as extruded pellets.

†Scandinavian LT-fish meal, Norsildmel, Norway.

$\ddagger$ Cargill, Staley, NC, USA.

$\S$ Denofa, Fredrikstad, Norway.

\| Statkorn, Oslo, Norway.

- Norsildmel, Norway.

** Oelmühle, Hamburg, Germany.

†† Denofa, Fredrikstad, Norway.

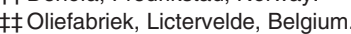

$\S \S$ Following the requirements reported by the National Research Council (1993). 
Table 2. Fatty acid composition of the diets $(\mathrm{g} / 100 \mathrm{~g}$ total fatty acid) (pellet sizes $0.5-2.2$ and $3-7 \mathrm{~mm}$ )

\begin{tabular}{|c|c|c|c|c|}
\hline & \multicolumn{2}{|c|}{ Diet F0100 } & \multicolumn{2}{|c|}{ Diet V0100 } \\
\hline & $0.5-2.2 \mathrm{~mm}$ & $3-7 \mathrm{~mm}$ & $0.5-2.2 \mathrm{~mm}$ & $3-7 \mathrm{~mm}$ \\
\hline $14: 0$ & $8 \cdot 1$ & 9.5 & $2 \cdot 3$ & $1 \cdot 7$ \\
\hline $16: 0$ & $13 \cdot 5$ & $13 \cdot 1$ & $17 \cdot 4$ & $18 \cdot 9$ \\
\hline $18: 0$ & $1 \cdot 3$ & 1.3 & $2 \cdot 4$ & 2.5 \\
\hline Saturates & 24.9 & $25 \cdot 8$ & $23 \cdot 6$ & 24.9 \\
\hline $16: 1$ & $9 \cdot 0$ & $9 \cdot 6$ & $2 \cdot 1$ & 1.4 \\
\hline $18: 1$ & $14 \cdot 6$ & $16 \cdot 0$ & $36 \cdot 0$ & $40 \cdot 6$ \\
\hline $20: 1$ & $15 \cdot 4$ & $16 \cdot 3$ & 3.5 & 1.9 \\
\hline $22: 1$ & $11 \cdot 5$ & $10 \cdot 7$ & $3 \cdot 1$ & $1 \cdot 4$ \\
\hline MUFA & $50 \cdot 6$ & $53 \cdot 2$ & 44.9 & $45 \cdot 4$ \\
\hline $18: 2 n-6$ & $3 \cdot 3$ & 3.8 & $12 \cdot 9$ & $14 \cdot 2$ \\
\hline $18: 3$ & $0 \cdot 1$ & $0 \cdot 1$ & 0.0 & 0.0 \\
\hline $20: 2$ & 0.2 & 0.2 & 0.1 & 0.1 \\
\hline $20: 4$ & 0.3 & 0.2 & $0 \cdot 1$ & 0.1 \\
\hline$n-6$ PUFA & $6 \cdot 0$ & $6 \cdot 0$ & 13.9 & $14 \cdot 8$ \\
\hline $18: 3 n-3$ & $1 \cdot 0$ & $1 \cdot 1$ & 8.7 & $10 \cdot 6$ \\
\hline $18: 4$ & 2.5 & $2 \cdot 0$ & 0.8 & 0.5 \\
\hline $20: 5$ & $5 \cdot 7$ & $4 \cdot 3$ & $2 \cdot 8$ & $1 \cdot 4$ \\
\hline $22: 6 n-3$ & $5 \cdot 2$ & 3.7 & $3 \cdot 1$ & 1.5 \\
\hline$n-3$ PUFA & $15 \cdot 5$ & $12 \cdot 0$ & $15 \cdot 9$ & $14 \cdot 2$ \\
\hline Saturates/PUFA & $1 \cdot 2$ & 1.4 & $0 \cdot 8$ & 0.8 \\
\hline$n-3 / n-6$ & $2 \cdot 6$ & $2 \cdot 0$ & $1 \cdot 1$ & 1.0 \\
\hline
\end{tabular}

\section{Proximate composition of diets}

Proximate composition of the diets was analysed using the following procedures: DM after drying at $105^{\circ} \mathrm{C}$ for $24 \mathrm{~h}$, fat by petroleum ether extraction (Soxtherm, Gerhardt, Germany) and gross energy in an adiabatic bomb calorimeter (IKA, Heitersheim Gribheimer, Germany). Protein content $(\mathrm{N} \times 6 \cdot 25)$ was determined by the Kjeldahl method after acid digestion. Cholesterol content of diets was determined by the Liebermann-Burchard reaction.

\section{Sampling procedure}

Samplings were made when rainbow trout reached market size of $1 \mathrm{~kg}$ (62 weeks of age) and at the intermediary size of $450 \mathrm{~g}$ (44 weeks of age). Fish were killed by a blow on the head $16 \mathrm{~h}$ after the meal in order to avoid the presence of chylomicrons in plasma. Liver from six fish for each dietary treatment were sampled to analyse the activity of FAS, G6PD and ME and the gene expression of FAS and G6PD. Whole fillet, without red muscle, of six fish per diet were collected for lipid content analyses. Nine other fish were also withdrawn to measure the activity and gene expression of LPL in white muscle (anterior-dorsal part), liver and perivisceral adipose tissue. All the tissues sampled were frozen in liquid nitrogen and stored at $-80^{\circ} \mathrm{C}$ until analysis.

From eighteen fish per diet at 44 weeks and twenty fish per diet at 62 weeks, blood was withdrawn over 0.01\% EDTA from the caudal vein, $16 \mathrm{~h}$ after feeding. Plasma was obtained by centrifugation at $3000 \mathrm{~g}$ for $10 \mathrm{~min}$. Sodium azide was added to the plasma (final concentration 0.04\%). Individual plasma sampled at 44 weeks was stored at $-20^{\circ} \mathrm{C}$ until the analysis of lipid class composition. For the final sampling (62 weeks), twenty plasma samples for each dietary treatment were pooled (four pools of five fish). An aliquot of each pool
$(5 \mathrm{ml})$ was used for lipoprotein fractionation and the remnants were stored at $-20^{\circ} \mathrm{C}$ until analysis of plasma lipid class composition.

\section{Lipids and fatty acid analyses}

Total lipids of diets were extracted according to Folch et al. (1957) and quantified gravimetrically. Fatty acid composition was determined on the total lipid extract. Fatty acid methyl esters were prepared by acid-catalysed transmethylation of total lipids using boron trifluoride in methanol according to Shantha \& Ackman (1990) and were analysed in a Varian 3800 gas chromatograph (Varian, Les Ulis, France). The chromatograph was equipped with a DB Wax fused silica capillary column $(30 \mathrm{~m} \times 0.25 \mathrm{~mm}$ internal diameter, film thickness $0.25 \mu \mathrm{m}$; J\&W Scientific, Folsom, CA, USA). Helium was used as carrier gas $(1.4 \mathrm{ml} / \mathrm{min})$ and the thermal gradient was $100-180^{\circ} \mathrm{C}$ at $8 \% \mathrm{~min}, 180-$ $220^{\circ} \mathrm{C}$ at $4 \% \mathrm{~min}$ and a constant temperature of $220^{\circ} \mathrm{C}$ for $20 \mathrm{~min}$. Injector and flame ionization detector temperatures were 260 and $250^{\circ} \mathrm{C}$, respectively. Fatty acid methyl esters were identified by comparison with known standard mixtures (Sigma, St Louis, MO, USA) and their relative proportions determined using a computer.

\section{Lipogenic enzymes and lipoprotein lipase assays}

For measurement of activities of lipogenic enzymes in liver, samples of liver were homogenized in three volumes of icecold buffer $(0.02 \mathrm{~mol} / \mathrm{l}$ Tris- $\mathrm{HCl}, 0.25 \mathrm{~mol} / \mathrm{l}$ sucrose, $2 \mathrm{mmol} /$ 1 EDTA, $0.1 \mathrm{~mol} / 1 \mathrm{NaF}, 0.5 \mathrm{mmol} / 1$ phenylmethylsulphonyl fluoride, 0.01 mol/1 $\beta$-mercaptoethanol, $\mathrm{pH} 7 \cdot 4)$. Homogenates were centrifuged at $15000 \mathrm{~g}$ for $20 \mathrm{~min}$ at $4^{\circ} \mathrm{C}$ and activities of lipogenic enzymes were measured on the supernatant. Activities of G6PD (EC 1.1.1.49) and ME (EC 1.1.1.40) were assayed according to the methods of Bautista et al. (1988) and Ochoa (1955), respectively, following NADPH production. FAS activity was performed by an isotopic method according to Hsu et al. (1969), measuring fatty acid synthesized from $\left[{ }^{14} \mathrm{C}\right]$ acetyl-CoA.

LPL activity was measured in liver, muscle and perivisceral adipose tissue. LPL assay was performed with $10 \%$ Intralipid (Fresenius Kabi, Sweden) which was labelled with tri[9,10- ${ }^{3-}$ $\mathrm{H}$ ]oleyl glycerol by sonication, and with rat serum as the source of apo C-II. Tissue samples $(1 \mathrm{~g})$ were homogenized in nine volumes of ice-cold buffer $(25 \mathrm{mmol} / \mathrm{l}$ ammonia, $5 \mathrm{mmol} / \mathrm{l}$ EDTA, $1 \%$ Triton X-100, $0.1 \%$ SDS, $1250 \mathrm{IU}$ heparin, $1 \mu \mathrm{l} / \mathrm{ml}$ pepstatin A, $10 \mu \mathrm{g} / \mathrm{ml}$ leupeptin, 4.25 IU aprotinin, $\mathrm{pH}$ 8.2). Homogenates were centrifuged at $20000 \mathrm{~g}$ at $4^{\circ} \mathrm{C}$ for $20 \mathrm{~min}$. The clear supernatant was recovered and LPL activity determined according to Bengtsson-Olivecrona \& Olivecrona (1992).

Enzyme activity units (IU), defined as $\mu \mathrm{mol}$ substrate converted to the product per min at the assay temperature $\left(25^{\circ} \mathrm{C}\right.$ for LPL assay and $30^{\circ} \mathrm{C}$ for lipogenic enzymes assays), were expressed per $\mathrm{mg}$ soluble protein (specific activity) and per gram of tissue (wet weight). Protein concentration of tissue homogenates was determined by the method of Bradford (1976) using a protein assay kit (Bio-Rad, Munich, Germany) with bovine serum albumin as a standard. 
Cloning of partial glucose-6-phosphate dehydrogenase and fatty acid synthetase cDNA of rainbow trout

For cloning G6PD cDNA partial sequence, primers were selected on the rainbow trout G6PD sequence (TIGR accession number TC38722) at positions 634-653 and 12361255 (Table 3). For cloning FAS cDNA partial sequence, primers were chosen on trout expressed sequence tag (tcaa 0001 c.m.06_5.1) issue of SIGENAE bank (French program of Analysis of Breeding Animals' Genome, AGENAE, http://www.sigenae.org) (Table 3).

Total hepatic RNA of rainbow trout, extracted with TRIzol reagent (Invitrogen, Carlsbad, CA, USA) were reverse transcripted in cDNA (Reverse Transcription System; Promega, Madison, WI, USA). Total RNA $(3 \mu \mathrm{l})$ was annealed with $0.25 \mu \mathrm{g}$ random primers and incubated with $15 \mathrm{U}$ avian myeloblastosis virus RT in a final volume of $20 \mu \mathrm{l}$, for $10 \mathrm{~min}$ at $25^{\circ} \mathrm{C}$ and $1 \mathrm{~h}$ at $42^{\circ} \mathrm{C}$. cDNA $(8 \mu \mathrm{l})$ was amplified by PCR using $16 \mathrm{pmol}$ of each primer in a reaction mixture containing $1.5 \mathrm{mmol} / 1 \mathrm{MgCl}_{2}, 50 \mathrm{mmol} / \mathrm{l} \mathrm{KCl}, 10 \mathrm{mmol} / \mathrm{l}$ Tris- $\mathrm{HCl}$, $0.1 \%$ Triton X-100, $0.2 \mathrm{mmol} / \mathrm{l} \mathrm{dNTP}$ and $4 \mathrm{U}$ Taq DNA polymerase (Promega), in a final volume of $100 \mu$ l. Forty cycles of denaturation, $20 \mathrm{~s}$ at $94^{\circ} \mathrm{C}$, annealing at annealing temperature (Table 3) for $20 \mathrm{~s}$ and extension at $72^{\circ} \mathrm{C}$ for $20 \mathrm{~s}$ were performed. PCR products were subjected to electrophoresis in $1 \%$ agarose gel, and fragments of the expected size range (620 bp for G6PD and 454 bp for FAS) were purified (Amicon, Millipore Corporation, Beldford, MA, USA). The purified DNA fragments were inserted into the $\mathrm{pCR}^{\circledR} 2 \cdot 1-\mathrm{TOPO}^{\circledR}$ plasmid and used for transformation of TOP10 One Shot ${ }^{\circledR}$ chemically competent cells (Invitrogen). Inserts were detected by Eco RI digestion of the extracted plasmid DNA. Clones with inserts were sequenced (Sequentia, Evry, France). Nucleotide sequences were compared: (1) for G6PD with DNA sequence of flounder (Platichthys flesus; EMBL accession number AJ310438.1) and fathead minnows (Pimephales promelas GenBank accession number AF206637.2); (2) for FAS with human (GenBank accession number BC014631.1) and chicken (GenBank accession number J04485.1) DNA sequences using the BLAST algorithm (Altschul et al. 1990). Sequence alignments and percentage of nucleotide conservation were assessed with the Clustal-W multiple alignment algorithm (Higgins \& Sharp, 1989) using the cloned trout G6PD or FAS sequences and sequences corresponding to the amplified regions from the species mentioned earlier.
Analysis of gene expression: real-time PCR and Northern blot

Analysis of FAS, G6PD and LPL gene expression was done at the first sampling time (44 weeks) and analysis of LDL-R gene expression was done at the final sampling (62 weeks) as analysis of composition of plasma lipoproteins was done at the final sampling. Analysis of FAS and G6PD gene expression was performed on trout liver and analysis of LPL and LDL-R gene expression was performed on trout white muscle, liver and perivisceral adipose tissue. Due to the low level of FAS, LPL and LDL-R gene expression, analysis of gene expression was performed using real-time RT-PCR in contrast to G6PD (analysis by Northern blot).

Total RNA was extracted from rainbow trout liver, white muscle and perivisceral adipose tissue using TRIzol reagent. To avoid genomic DNA amplification during real-time RTPCR, RNA extracted from liver and muscle was treated by RQ1 RNase-Free DNase (Promega) prior to RT-PCR. This was not done on RNA extracted from adipose tissue because of the low concentration of RNA in this tissue. Total RNA was quantified based on absorbance at $260 \mathrm{~nm}$. cDNA were generated from $1 \mu \mathrm{g}$ DNase-treated RNA using $200 \mathrm{U}$ SuperScript $^{\mathrm{TM}}$ III RT (Invitrogen) and $500 \mathrm{ng}$ oligo $(\mathrm{dT})_{15}$ primers (Promega) in a total volume of $20 \mu$ l. For each sample, reverse transcription was performed in duplicate. Real-time PCR was performed with the iCycler $\mathrm{iQ}^{\mathrm{TM}}$ (Bio-Rad, Hercules, CA, USA) on $10 \mu$ RT reaction using $\mathrm{iQ}^{\mathrm{TM}} \mathrm{SYBR}^{\circledR}$ Green Supermix (Bio-Rad). The total volume of the PCR reaction was $25 \mu \mathrm{l}$, containing $200 \mathrm{nmol} / \mathrm{l}$ primers. Primers for LPL mRNA amplification were chosen at positions 445-464 and 590-608 of rainbow trout cDNA LPL sequence (GenBank accession number AJ224693) (Table 3). Primers for FAS mRNA amplification were selected on the sequence of the rainbow trout FAS cDNA fragment cloned (Table 3). For LDL-R mRNA amplification, primers were chosen at positions 1118-1137 and 1284-1303 of rainbow trout cDNA LDL-R sequence (Genbank accession number AF542091) (Table 3). Primers were defined with Primer3 software. Forward primers for LPL and FAS mRNA amplification were overlapping an intron. Thermal cycling was initiated with the incubation at $95^{\circ} \mathrm{C}$ for $3 \mathrm{~min}$ for hot-start $\mathrm{iTaq}^{\mathrm{TM}}$ DNA polymerase activation. Thirty-five steps of PCR were performed, each one consisting of heating at $95^{\circ} \mathrm{C}$ for $20 \mathrm{~s}$ for denaturing, and at $59^{\circ} \mathrm{C}$ for $30 \mathrm{~s}$ for annealing and extension. Following the final cycle of the PCR, melting curves were systematically monitored (increase set-point temperature from 55 to $94^{\circ} \mathrm{C}$

Table 3. Nucleotide sequences of the primers used for cDNA cloning sequences and the primers used to assay gene expression by real-time PCR

\begin{tabular}{|c|c|c|c|c|}
\hline & Forward primer & Reverse primer & $\begin{array}{c}\text { Annealing } \\
\text { temperature }\left({ }^{\circ} \mathrm{C}\right)\end{array}$ & $\begin{array}{l}\text { PCR product } \\
\text { length (bp) }\end{array}$ \\
\hline \multicolumn{5}{|c|}{ Primers for cDNA cloning } \\
\hline G6PD & cactacctgggcaaggagat & ttgctcatcatcttggcgta & 55 & 620 \\
\hline FAS & tacgccaattctgccatgga & tcttgttgatggtgagctgt & 54 & 454 \\
\hline \multicolumn{5}{|c|}{ Primers for real-time PCR } \\
\hline FAS & gagacctagtggaggctgtc & tcttgttgatggtgagctgt & 59 & 186 \\
\hline LPL & taattggctgcagaaaacac & cgtcagcaaactcaaaggt & 59 & 164 \\
\hline LDL-R & aactgcggtcacaggtcaaa & acggggttgtcaaagtggat & 59 & 186 \\
\hline $\mathrm{EF} 1 \alpha$ & tcctcttggtcgtttcgetg & acccgagggacatcctgtg & 59 & 159 \\
\hline
\end{tabular}

EF1 $\alpha$, elongation factor $1 \alpha$; FAS, fatty acid synthetase; G6PD, glucose-6-phosphate dehydrogenase; LDL-R, LDL receptor; LPL, lipoprotein lipase. 
by $0.5^{\circ} \mathrm{C} / 10 \mathrm{~s}$ ). Relative quantification of the target gene transcript with the elongation factor $1 \alpha$ transcript was made following the Pfaffl method with the Relative Expression Software Tool (RESTC; Pfaffl et al. 2002). This mathematical algorithm, which needs no calibration curve, computes an expression ratio $(R)$, based on real-time PCR efficiency and the crossing-point deviation of the unknown sample (diet VO100) versus the control (diet FO100):

$$
\begin{aligned}
R= & {\left[\left(E_{\text {gene }}\right)^{\Delta C T \text { gene }(\text { mean FO100 }- \text { mean VO100 })}\right] / } \\
& {\left[\left(E_{\mathrm{EF} 1 \alpha}\right)^{\Delta \mathrm{CTEF1} \alpha(\text { mean FO100-mean VO100) }}\right], }
\end{aligned}
$$

where $E$ is PCR efficiency determined by a standard curve using serial dilution of cDNA; $\triangle C T$ is the crossing-point deviation of an unknown sample (VO100) versus a control (FO100); and $\mathrm{EF} 1 \alpha$ is elongation factor $1 \alpha$.

Hepatic G6PD gene expression was determined by Northern blot. Total extracted RNA $(20 \mu \mathrm{g})$ from rainbow trout liver was submitted to electrophoresis in $1 \%$ agarose gel containing $5 \%$ formaldehyde and capillary transferred on to nylon membrane (Hybond-N ${ }^{+}$; Amersham, UK). After transfer, RNA blots were stained with methylene blue to locate $28 \mathrm{~S}$ and $18 \mathrm{~S}$ rRNA and to determine the relative amounts of loaded RNA. Membranes were hybridized with rainbow trout $\alpha^{32} \mathrm{P}$ labelled G6PD DNA probes labelled by random priming (Stratagene, La Jolla, CA, USA). After stringent washing $(2 \times$ saline sodium citrate (SSC) for $15 \mathrm{~min} ; 0.5 \times \mathrm{SSC}, 0.1 \%$ SDS for $15 \mathrm{~min} ; 0.1 \times$ SSC, $0.1 \%$ SDS for $15 \mathrm{~min} ; 0.1 \times$ SSC, $1 \%$ SDS for $15 \mathrm{~min}$ ), the membrane was exposed to $\mathrm{X}$-ray film (Merck Eurolab, Nogent-sur-Marne, France) and the resulting images were quantified using Visio-Mic II software (Genomic, Lyon, France).

\section{Separation of lipoproteins and analysis of lipid composition} of plasma and lipoprotein classes

VLDL, LDL and HDL were obtained by sequential ultracentrifugal flotation of plasma as Torstensen et al. (2000), using a Kontron T-2060 ultracentrifuge (Kontron Instruments, St Quentin-en-Yvelines, France) equipped with a TFT 65.13 rotor. The density intervals were obtained by addition of $\mathrm{KBr}$ solution containing $0.04 \% \mathrm{NaN}_{3}$ and $0.01 \%$ EDTA. The density intervals were: VLDL, $<1.015 \mathrm{~g} / \mathrm{ml}$; LDL, 1.015 to $<1.085 \mathrm{~g} / \mathrm{ml}$; HDL, 1.085 to $<1.21 \mathrm{~g} / \mathrm{ml}$. Purity of the different fractions was verified by agarose gel electrophoresis.

Concentrations of triacylglycerol, total cholesterol, phospholipid and NEFA were determined on plasma and lipoproteins fractions by colorimetric enzymatic methods using commercial kits (Triglycérides PAP 150, Cholestérol RTU and Phospholipides PAP 150 from Biomérieux, Marcy I'Etoile France; NEFA C from Wako Chemicals GmbH, Neuss, Germany). Concentration of protein was determined by the method of Bradford (1976).

\section{Statistical analysis}

Results are expressed as means and standard deviations. Data were analysed by one-way ANOVA to test the effect induced by dietary treatments on enzyme activities, lipid and protein composition of plasma and lipoprotein classes. Means were compared using Duncan's test. Differences were considered to be significant at $P=0.05$. All statistics were performed using Statistical Analysis Systems statistical package software version 7.4 (SAS Institute, Cary, NC, USA).

\section{Results}

Growth performance of rainbow trout was similar all along the long-term study, irrespective of dietary treatment and the two groups reached a final body weight of around $1 \mathrm{~kg}$ at the end of the feeding experiment (Table 4). Among the two groups of fish, no significant differences were observed in feed efficiency (weight gain $(\mathrm{g}) /$ feed intake $(\mathrm{g})$ ), which was 0.95 (SD 0.04) for group FO100 and 0.95 (SD 0.08) for group VO100. Liver to body weight ratio was the same for each dietary treatment at 44 and 62 weeks and was lower at both sampling times in trout fed diet VO100 (Table 4). Viscerosomatic index was higher at 62 than 44 weeks and did not significantly differ between dietary treatments (Table 4). No significant differences were found between groups of trout for muscle lipid content at 44 and 62 weeks (Table 4).

FAS, G6PD and ME activities measured in liver of rainbow trout fed diets for 44 and 62 weeks are presented in Fig. 1. After 44 weeks, hepatic G6PD activity was about 3.3 times higher than ME activity. Dietary treatment had no effect on FAS, ME and G6PD activities when expressed per g liver or per mg protein (data not shown), at the two sampling times. At the end of the study (62 weeks), activities of the three lipogenic enzymes were higher than at 44 weeks and G6PD activity was about 1.5 times higher than ME activity.

Analysis of G6PD and FAS gene expression was undertaken at 44 weeks (Tables 5A,B). The G6PD mRNA observed was around $1.8 \mathrm{~kb}$. Expression of the G6PD gene was not significantly different between the two groups of rainbow trout. As FAS gene expression was very low, its analysis was performed using real-time RT-PCR and computed using

Table 4. Morphometric parameters and muscle lipid content of rainbow trout fed diets at $44(n 18)$ and 62 weeks $(n 15)^{*}$

\begin{tabular}{|c|c|c|c|c|}
\hline & \multicolumn{2}{|c|}{ Diet FO100 } & \multicolumn{2}{|c|}{ Diet V0100 } \\
\hline & Mean & SD & Mean & SD \\
\hline \multicolumn{5}{|l|}{44 weeks } \\
\hline FBW $(g)$ & 459 & 21 & 463 & 8 \\
\hline $\mathrm{HSI}+$ & $1 \cdot 0^{\mathrm{a}}$ & 0.1 & $0.9^{b}$ & 0.1 \\
\hline VSI & $9 \cdot 2$ & 1.4 & $8 \cdot 7$ & $1 \cdot 3$ \\
\hline Muscle lipids (\% fresh) & $10 \cdot 3$ & $1 \cdot 2$ & 9.9 & 0.9 \\
\hline \multicolumn{5}{|l|}{62 weeks } \\
\hline FBW (g) & 1011 & 40 & 1019 & 63 \\
\hline $\mathrm{HSI}+$ & $1 \cdot 0^{\mathrm{a}}$ & 0.1 & $0.9^{\mathrm{b}}$ & 0.1 \\
\hline VSI‡ & $10 \cdot 2$ & 1.5 & $9 \cdot 2$ & 1.6 \\
\hline Muscle lipids (\% fresh) & $12 \cdot 5$ & $3 \cdot 1$ & $11 \cdot 0$ & 0.7 \\
\hline \multicolumn{5}{|c|}{$\begin{array}{l}\text { FBW, final body weight. } \\
\text { a,b Mean values within a row with unlike superscript letters were significantly differ- } \\
\text { ent }(P<0.05) \text {. }\end{array}$} \\
\hline \multicolumn{5}{|c|}{$\begin{array}{l}{ }^{*} \text { For details of procedures and diets, see p. } 300-302 \text { and Tables } 1 \text { and } 2 \text {. } \\
\dagger \text { Hepatosomatic index }(\mathrm{HSI})=(\text { liver weight/body weight }) \times 100 \text {. } \\
\ddagger \text { Viscerosomatic index }(\mathrm{VSI})=(\text { viscera weight/body weight }) \times 100 \text {. }\end{array}$} \\
\hline
\end{tabular}

(Mean values and standard deviations) 


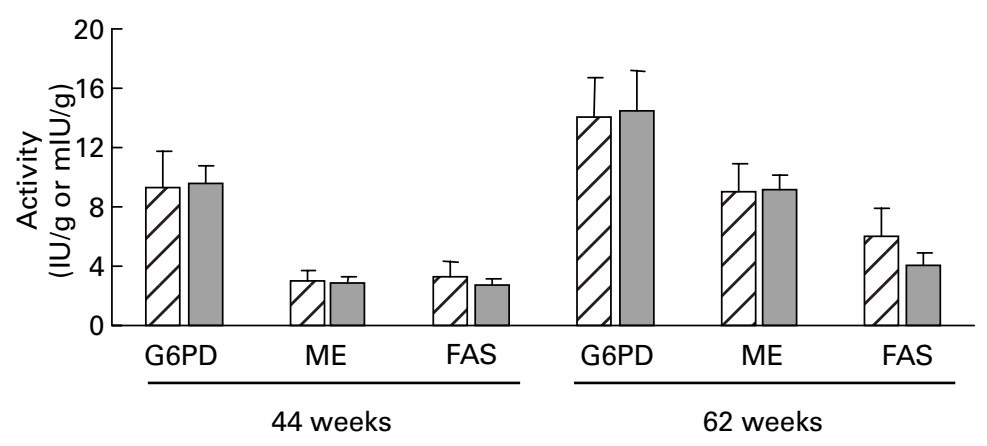

Fig. 1. Activities of glucose-6-phosphate dehydrogenase (G6PD), malic enzyme (ME) and fatty acid synthetase (FAS) in liver of rainbow trout after 44 and 62 weeks of feeding with diet FO100 (Z) or diet VO100 ( $\square$ ). For details of procedures and diets, see pp. 300-303 and Tables 1 and 2. Values are expressed in IU (G6PD and ME) or mIU/g tissue (FAS). Values are means with their standard deviation depicted by vertical bars $(n 6)$. Means values were not significantly different for a selected enzyme between dietary groups $(P<0.05)$.

Table 5A. Gene expression analysis at 44 weeks by real-time PCR: comparison of fatty acid synthetase (FAS; liver), LPL (lipoprotein lipase; liver, white muscle and perivisceral adipose tissue) and LDL receptor (LDL-R; liver, white muscle and perivisceral adipose tissue) gene expression, diet VO100 compared to diet FO100 (n 6)*

\begin{tabular}{lcccc}
\hline Gene & $x$-Fold $\dagger$ & $P$ value & $\begin{array}{c}\mathrm{CV}_{\text {VO100 }} \\
(\%)\end{array}$ & $\begin{array}{c}\mathrm{CV}_{\mathrm{FO} 100} \\
(\%)\end{array}$ \\
\hline FAS (liver) & -1.01 & 0.978 & 5.1 & 8.1 \\
LPL (liver) & -2.11 & 0.023 & 5.5 & 2.4 \\
LPL (white muscle) & +1.04 & 0.894 & 14.9 & 5.7 \\
LPL (adipose tissue) & -1.54 & 0.046 & 5.6 & 9.2 \\
LDL-R (liver) & -3.92 & 0.002 & 2.4 & 3.5 \\
LDL-R (white muscle) & -2.10 & 0.098 & 4.5 & 7.6 \\
LDL-R (adipose tissue) & -1.57 & 0.001 & 1.2 & 1.4 \\
\hline
\end{tabular}

* For details of procedures and diets, see pp. 300-303 and Tables 1 and 2.

†Alterations in mRNA expression are presented as an $x$-fold up- $(+)$ or down- $(-)$ regulation (statistical $\mathrm{REST}^{\mathcal{O}}$ analyses; Pfaffl et al. 2002). Expression results were normalized by elongation factor $1 \alpha$ gene expression.

REST $^{(}$. FAS gene expression of fish fed diets FO100 and VO100 were not significantly differentially regulated.

Triacylglycerol, total cholesterol, phospholipid, NEFA and total protein were analysed in plasma after 44 and 62 feeding weeks (Table 6). The level of triacylglycerol in plasma increased about 3 -fold from 44 weeks to the final sampling. Levels of cholesterol, phospholipid, NEFA and protein were quite the same for the two sampling times. Replacement of fish oil by the vegetable oil blend lowered phospholipid and cholesterol levels in plasma at 44 and 62 weeks. Plasma

Table 5B. Gene expression analysis at 44 weeks by Northern blot: glucose-6-phosphate dehydrogenase (G6PD) gene expression in the liver $(n 9)^{\star}$

(Mean values and standard deviations)

\begin{tabular}{lccccc}
\hline & \multicolumn{2}{c}{ FO100 } & & \multicolumn{2}{c}{ VO100 } \\
\cline { 2 - 3 } Gene & Meant & SD & & Meant & SD \\
\hline $\begin{array}{l}\text { G6PD mRNA/18S rRNA } \\
\text { (arbitary units) }\end{array}$ & 0.89 & 0.22 & & 0.99 & 0.27
\end{tabular}

* For details of procedures and diets, see pp. 300-303 and Tables 1 and 2. The G6PD mRNA was around $1.8 \mathrm{~kb}$. The 18S rRNA served as an internal control for loading.

†Mean values were not significantly different (Duncan's test, $P<0.05$ ).
NEFA level was decreased by diet VO100 at 44 weeks but there were no significant differences between the two groups of fish at 62 weeks. Levels of triacylglycerol and protein in plasma did not differ with dietary treatment at either sampling time.

Plasma lipoprotein classes (VLDL, LDL, HDL) were separated after 62 weeks of feeding and their composition of triacylglycerol, total cholesterol, phospholipid, NEFA and total protein was determined. The level of analysed components of the VLDL, LDL and HDL classes is expressed as concentration in lipoproteins of plasma (Table 7) and as percentage of lipoprotein fraction (Table 8). When results were expressed as concentration in lipoproteins of total plasma, the VO100 group had a lower level of cholesterol in the three lipoprotein classes and had a lower level of all components analysed in the LDL fraction. Amounts of VLDL and HDL were unchanged by dietary treatment whereas the amount of LDL was reduced by around $40 \%$ with diet VO100. When components analysed were expressed as percentage of lipoprotein fraction there were no significant differences in the composition of LDL and HDL fractions between dietary groups. In the VLDL fraction, triacylglycerol and NEFA levels were

Table 6. Triacylglycerol, total cholesterol, phospholipid, NEFA and total protein in rainbow trout plasma $(\mathrm{g} / \mathrm{l})$ at $44(n 18)$ and 62 weeks $(n 4)^{\star}$ (Mean values and standard deviations)

\begin{tabular}{|c|c|c|c|c|}
\hline & \multicolumn{2}{|c|}{ Diet F0100 } & \multicolumn{2}{|c|}{ Diet V0100 } \\
\hline & Mean & SD & Mean & SD \\
\hline \multicolumn{5}{|l|}{44 weeks } \\
\hline Triacylglycerol (g/l) & $4 \cdot 08$ & 1.4 & 3.51 & 0.90 \\
\hline Cholesterol $(\mathrm{g} / \mathrm{l})$ & $7 \cdot 88^{a}$ & 1.92 & $4 \cdot 50^{\mathrm{b}}$ & 0.63 \\
\hline Phospholipid (g/l) & $12 \cdot 05^{a}$ & $2 \cdot 15$ & $8 \cdot 90^{\mathrm{b}}$ & 1.37 \\
\hline $\operatorname{NEFA}(\mathrm{g} / \mathrm{l})$ & $0.25^{a}$ & 0.04 & $0 \cdot 16^{\mathrm{b}}$ & 0.02 \\
\hline Protein (g/l) & 37.97 & 5.03 & $39 \cdot 24$ & 4.85 \\
\hline \multicolumn{5}{|l|}{62 weeks } \\
\hline Triacylglycerol (g/l) & $10 \cdot 28$ & 1.54 & 9.90 & $1 \cdot 23$ \\
\hline Cholesterol (g/l) & $6 \cdot 45^{\mathrm{a}}$ & 1.07 & $3.97^{\mathrm{b}}$ & 0.23 \\
\hline Phospholipid (g/l) & $13 \cdot 20^{a}$ & 1.45 & $10 \cdot 44^{\mathrm{b}}$ & 0.98 \\
\hline $\operatorname{NEFA}(g / l)$ & 0.38 & 0.05 & 0.33 & 0.08 \\
\hline Protein $(\mathrm{g} / \mathrm{l})$ & 42.96 & 4.99 & $40 \cdot 97$ & 2.47 \\
\hline
\end{tabular}

${ }^{*}$ For details of procedures and diets, see pp. 300-303 and Tables 1 and 2.

a,b Mean values within a row with unlike superscript letters were significantly different $(P<0.05)$ 
Table 7. Triacylglycerol, total cholesterol, phospholipid, NEFA and protein in VLDL, LDL and HDL expressed as concentration in lipoproteins of plasma ( $\mathrm{g} / \mathrm{l}$ plasma) and amount of lipoprotein class ( $\mathrm{g} / \mathrm{l}$ plasma) after 62 weeks of feeding $(n 4)^{\star}$

(Mean values and standard deviations)

\begin{tabular}{|c|c|c|c|c|}
\hline & \multicolumn{2}{|c|}{ Diet F0100 } & \multicolumn{2}{|c|}{ Diet V0100 } \\
\hline & Mean & SD & Mean & SD \\
\hline \multicolumn{5}{|l|}{ VLDL } \\
\hline Triacylglycerol & $4 \cdot 16$ & 0.48 & $4 \cdot 16$ & $1 \cdot 37$ \\
\hline Cholesterol & $1 \cdot 48^{a}$ & 0.24 & $0.80^{\mathrm{b}}$ & 0.32 \\
\hline Phospholipid & 1.99 & 0.31 & 1.45 & 0.49 \\
\hline NEFA & $0.020^{\mathrm{b}}$ & 0.004 & $0.031^{a}$ & 0.003 \\
\hline Protein & 1.04 & 0.16 & 0.72 & 0.20 \\
\hline Amount VLDL & $8 \cdot 70$ & $1 \cdot 14$ & $7 \cdot 17$ & $2 \cdot 38$ \\
\hline \multicolumn{5}{|l|}{ LDL } \\
\hline Triacylglycerol & $2.69^{a}$ & 0.37 & $1 \cdot 85^{\mathrm{b}}$ & 0.27 \\
\hline Cholesterol & $2 \cdot 22^{a}$ & 0.48 & $1 \cdot 25^{\mathrm{b}}$ & 0.15 \\
\hline Phospholipid & $3 \cdot 37^{a}$ & 0.56 & $2 \cdot 03^{b}$ & 0.13 \\
\hline NEFA & 0.022 & 0.009 & 0.011 & 0.005 \\
\hline Protein & $3.95^{\mathrm{a}}$ & 0.68 & $2 \cdot 29^{\mathrm{b}}$ & 0.15 \\
\hline Amount LDL & $12 \cdot 25^{a}$ & 2.02 & $7 \cdot 43^{\mathrm{b}}$ & 0.31 \\
\hline \multicolumn{5}{|l|}{$\mathrm{HDL}$} \\
\hline Triacylglycerol & 1.43 & 0.24 & $1 \cdot 30$ & 0.20 \\
\hline Cholesterol & $1 \cdot 38^{a}$ & $0 \cdot 10$ & $1 \cdot 10^{\mathrm{b}}$ & 0.12 \\
\hline Phospholipid & 4.68 & 0.28 & $4 \cdot 28$ & 0.27 \\
\hline NEFA & 0.072 & 0.008 & 0.061 & 0.007 \\
\hline Protein & 6.90 & 0.50 & $6 \cdot 15$ & 0.51 \\
\hline Amount HDL & 14.45 & 0.96 & 12.89 & 0.92 \\
\hline
\end{tabular}

${ }^{*}$ For details of procedures and diets, pp. 300-303 and Tables 1 and 2.

a,b Mean values within a row with unlike superscript letters were significantly different $(P<0 \cdot 05)$.

raised in trout fed diet VO100 whereas cholesterol, phospholipid and protein levels were decreased.

Data on LDL-R mRNA expression in perivisceral adipose tissue, white muscle and liver of rainbow trout at 62 weeks are reported in Tables 5A. In perivisceral adipose tissue and in liver, LDL-R gene expression was significantly down-regulated (by a factor of 1.6 and $3 \cdot 9$, respectively) in fish fed diet VO100. In the white muscle, LDL-R gene expression was not significantly different between the two dietary groups.
Table 8. Triacylglycerol, total cholesterol, phospholipid, NEFA and protein in VLDL, LDL and HDL expressed as a percentage of the lipoprotein fraction after 62 weeks of feeding $(n 4)^{*}$

(Mean values and standard deviations)

\begin{tabular}{|c|c|c|c|c|}
\hline & \multicolumn{2}{|c|}{ Diet FO100 } & \multicolumn{2}{|c|}{ Diet V0100 } \\
\hline & Mean & SD & Mean & SD \\
\hline \multicolumn{5}{|l|}{ VLDL } \\
\hline Triacylglycerol (\%) & $47 \cdot 9^{b}$ & 1.9 & $58 \cdot 1^{a}$ & 0.4 \\
\hline Cholesterol (\%) & $17 \cdot 0^{\mathrm{a}}$ & $1 \cdot 1$ & $10 \cdot 9^{b}$ & 0.9 \\
\hline Phospholipid (\%) & $22 \cdot 9^{a}$ & 0.9 & $20 \cdot 3^{b}$ & 0.3 \\
\hline NEFA (\%) & $0 \cdot 24^{b}$ & 0.08 & $0.47^{\mathrm{a}}$ & 0.14 \\
\hline Protein (\%) & $11.9^{\mathrm{a}}$ & 0.5 & $10 \cdot 2^{b}$ & 0.6 \\
\hline \multicolumn{5}{|l|}{ LDL } \\
\hline Triacylglycerol (\%) & $22 \cdot 0$ & $1 \cdot 3$ & $24 \cdot 9$ & 3.5 \\
\hline Cholesterol (\%) & $18 \cdot 0$ & 1.5 & $16 \cdot 8$ & $1 \cdot 7$ \\
\hline Phospholipid (\%) & $27 \cdot 5$ & $0 \cdot 7$ & $27 \cdot 3$ & 0.7 \\
\hline $\operatorname{NEFA}(\%)$ & 0.17 & 0.05 & 0.14 & 0.06 \\
\hline Protein (\%) & $32 \cdot 2$ & 1.0 & $30 \cdot 9$ & $1 \cdot 8$ \\
\hline \multicolumn{5}{|l|}{ HDL } \\
\hline Triacylglycerol (\%) & $9 \cdot 9$ & 1.5 & $10 \cdot 1$ & 1.4 \\
\hline Cholesterol (\%) & 9.5 & 0.1 & $8 \cdot 6$ & 0.7 \\
\hline Phospholipid (\%) & $32 \cdot 4$ & $1 \cdot 1$ & $33 \cdot 2$ & 0.7 \\
\hline NEFA (\%) & 0.50 & 0.03 & 0.48 & 0.07 \\
\hline Protein (\%) & $47 \cdot 7$ & 0.5 & $47 \cdot 7$ & $1 \cdot 3$ \\
\hline
\end{tabular}

* For details of procedures and diets, see pp. 300-303 and Tables 1 and 2.

a,b Mean values within a row with unlike superscript letters were significantly different $(P<0.05)$

LPL activity measured in perivisceral adipose tissue, white muscle and liver of trout fed diets for 44 weeks and 62 weeks is shown in Fig. 2. LPL activity was higher in adipose tissue than in muscle and liver (about eight and four times, respectively) at the two sampling times. After 44 weeks of feeding, LPL activity in adipose tissue and white muscle did not differ among the two groups whereas in liver, LPL activity was reduced in fish fed diet VO100. At the end of the experiment (62 weeks), in the three tissues studied, LPL activity was lower than at 44 weeks. No significant differences in LPL activity were observed between the groups whatever the tissue after 62 weeks of feeding.

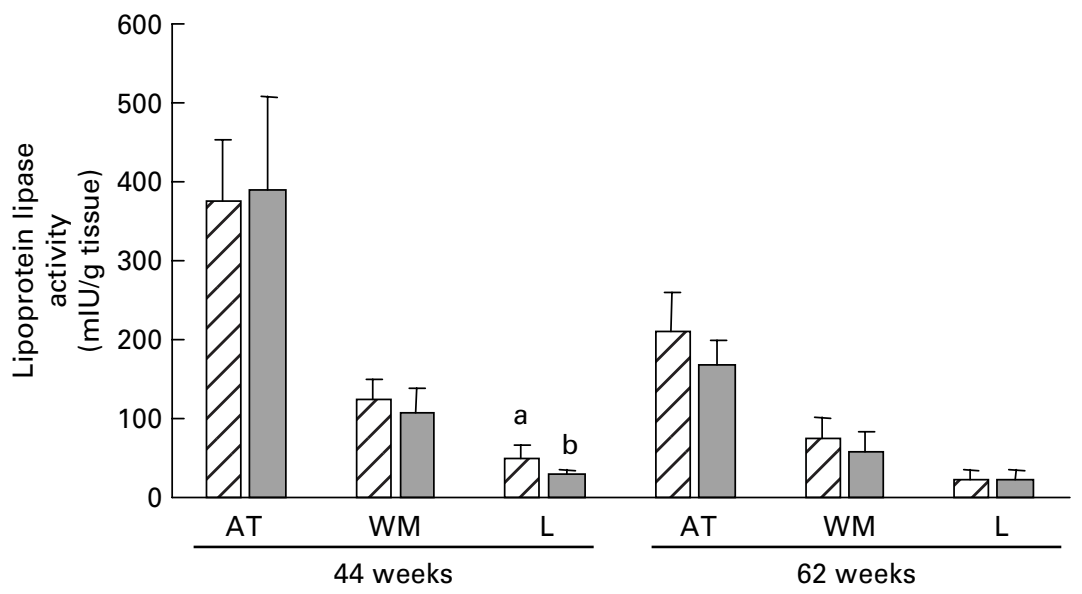

Fig. 2. Lipoprotein lipase activity in perivisceral adipose tissue (AT), white muscle (WM) and liver (L) of rainbow trout after 44 and 62 weeks of feeding with diet FO100 ( $\triangle$ ) or diet VO100 ( $\square$ ). For details of procedures and diets, see pp. 300-303 and and Tables 1 and 2 . Values are means with their standard deviation depicted by vertical bars $(n 9)$. ${ }^{a, b}$ Mean values within dietary groups for a selected tissue with unlike superscript letters were significantly different $(P<0.05)$. 
At 44 weeks, analysis of LPL gene expression was done by real-time RT-PCR in the three tissues (Tables 5A). In fish fed diet VO100, LPL gene expression was $2 \cdot 1$-fold down-regulated in liver and slightly lowered in adipose tissue (1.5-fold, $P=0.046)$. In white muscle, LPL gene expression was not affected by dietary treatments.

\section{Discussion}

Studies have reported that partial replacement (at least 50\%, up to $80 \%$ ) of dietary fish oil by vegetable oils (soyabean oil, rapeseed oil, blends of olive and palm oils or rapeseed and palm oils) in rainbow trout with initial weight $250 \mathrm{~g}$ (Caballero et al. 2002) and total replacement by soyabean oil or linseed oil in rainbow trout with initial weight $80 \mathrm{~g}$ (Greene \& Selivonchick, 1990) did not have a negative impact on fish growth. The present study is the first ever in rainbow trout to demonstrate that it is possible to replace totally fish oil by a blend of vegetable oils right from firstfeeding up to a body weight of $1 \mathrm{~kg}$ without compromising their growth or feed nutrient utilization. Several parameters of flesh quality were also assessed and no differences in sensory quality were found (unpublished results). Total replacement of fish oil by palm oil, oleic acid-enriched sunflower oil, rapeseed oil, or a blend of rapeseed and linseed oils in Atlantic salmon (Torstensen et al. 2000; Bell et al. 2001, 2002; Bendiksen et al. 2003) or by soyabean or rapeseed oils in brook charr (Guillou et al. 1995), do not also seem to have any significant effect on growth.

The increase in hepatic lipogenic enzyme activities between the two sampling times is in agreement with the observations of Walzem et al. (1991) who showed that activities of G6PD and ME (IU/liver) correlated by a regression coefficient of 0.87 and 0.88 , respectively, with body mass gains of fish. This increase in lipid neo-synthesis could contribute to the rise in lipid content of fish with age. G6PD activity was about 1.5 -fold higher than ME activity. This is in accordance with earlier data that the pentose phosphate pathway is the principal purveyor of cytoplasmic reducing equivalent NADPH in rainbow trout (Walzem et al. 1991; Hung \& Storebakken, 1994; Gelineau et al. 2001) as in European seabass (Dias et al. 1998), coho salmon (Lin et al. 1977), turbot (Regost et al. 2001) or gilthead sea bream (Gomez-Requeni et al. 2003). In Atlantic salmon, however, G6PD activity is reported to be lower than that of ME (Menoyo et al. 2003; Torstensen et al. 2004).

Studies of Menoyo et al. (2003) indicated that in Atlantic salmon, G6PD and ME activities were higher with a low $n$ 3 PUFA diet (29\% v. $15 \%$ of the total fatty acids). Alvarez et al. (2000) also observed in vitro an inhibitory effect of EPA, DHA and linolenic acid on G6PD and FAS activities in rainbow trout hepatocytes. In gilthead sea bream, linseed oil, rich in linolenic acid, also induces a decrease in hepatic lipogenesis (Menoyo et al. 2004) although in turbot it has no effect (Regost et al. 2003), possibly indicating inter-species differences. In the present study, replacing fish oil by the blend of vegetable oils did not modify hepatic lipogenesis in rainbow trout, either at the molecular or enzymatic levels. Similar results on enzyme activities have been observed in gilthead sea bream and turbot fed soyabean oil (Regost et al. 2003; Menoyo et al. 2004) and in Atlantic salmon fed graded levels of rapeseed oil (Torstensen et al. 2004). This lack of effect may be due to the fact that in these vegetable oilbased diets, both the increase in linolenic acid and the decrease in EPA and DHA are too low to induce significant changes in lipogenesis.

With around $13.5 \mathrm{~g} / \mathrm{l}$ plasma, HDL was the dominant lipoprotein class in plasma of rainbow trout, as in all teleosts (Babin \& Vernier, 1989). The lipid composition of lipoprotein classes of rainbow trout was in accordance with the data of Chapman et al. (1978) and Babin \& Vernier (1989). The major component of the VLDL class was triacylglycerol (around 53\% of fraction), reflecting its major role in the transport of triacylglycerol from the liver to the tissues where they will be stored or oxidized (Sheridan, 1988; Tocher, 2003). LDL, resulting from VLDL hydrolysis, contained less triacylglycerol $(23.5 \%)$ than VLDL and was the richest class in cholesterol $(17 \%)$. The HDL class contained mainly protein $(48 \%)$ and phospholipid (33\%).

The decrease in plasma cholesterol level by around $40 \%$ at both sampling times with the diet containing the vegetable oil blend appeared to be due to a decrease in the amount of plasma LDL, as shown by plasma lipoprotein analyses performed at the final sampling. Plasma LDL amount was lowered by similar levels to plasma total cholesterol after 62 weeks of feeding.

In many species, plasma total cholesterol and LDL cholesterol concentrations increase with the addition of cholesterol to the diet (Spady \& Dietschy, 1988; Grundy \& Denke, 1990; Mustad et al. 1996; Matsuyama et al. 2005). In the present study, the difference in cholesterol content of the diets ( $2.1 \%$ total lipid for diet FO100 and $1.3 \%$ for diet VO100) seems to be too low to mainly explain the hypocholesterolaemic effect of vegetable oils. The nature of dietary fatty acid is also known to affect plasma cholesterol concentration. In mammals, an increase in dietary saturated fatty acids induces a rise in plasma LDL cholesterol whereas oleic acid and PUFA reduce this level (Grundy \& Denke, 1990; Fernandez \& West, 2005). In the present study, the decrease in plasma cholesterol and LDL when rainbow trout were fed with the vegetable oil diet could be related to the higher levels of oleic and linolenic acids in this diet. Several studies have shown that the effect of dietary fatty acids on the amount of plasma LDL is mainly mediated by modifications of plasma LDL clearance which occur via LDL-R-mediated uptake. Thus hepatic LDL-R activity was found to be impaired by saturated fatty acids and increased by PUFA (Dietschy, 1998; Fernandez \& West, 2005). In hamster and pig, changes in hepatic LDL-R activity induced by dietary fatty acids were accompanied by parallel changes in hepatic LDL-R protein and mRNA levels (Horton et al. 1993; Mustad et al. 1996). Nevertheless, in the present study, with diet VO100, we observed a down-regulation of LDL-R gene expression in the liver (3.9-fold) and to a lesser extent in adipose tissue (1.6-fold). Studies undertaken in primates also did not find any apparent relationship between changes in hepatic LDL-R mRNA level and changes in plasma LDL cholesterol concentration induced by saturated or unsaturated fats (Fox et al. 1987; Sorci-Thomas et al. 1989). Another way by which dietary fatty acids possibly affect plasma LDL clearance involve membrane fluidity as reported by Kuo et al. (1990), who showed an increase in LDL binding and 
uptake when hepatocyte membrane fluidity is increased by unsaturated fatty acid enrichment. Further work on LDL-R activity and affinity in rainbow trout will be useful in order to confirm whether the response observed on LDL-R gene expression with replacement of dietary fish oil by vegetable oils is typical for this species.

Plant oils also contain phytosterols (Phillips et al. 2002) which are known to decrease total cholesterol and LDL cholesterol in man (Moghadasian \& Frohlich, 1999; Matvienko et al. 2002; Vanstone et al. 2002) as well as in some teleosts (Gilman et al. 2003), by decreasing intestinal cholesterol absorption efficiency (Normen et al. 2000; Vanstone et al. 2002). Indeed phytosterols have a higher affinity than cholesterol for binding to bile acid micelles in the intestinal lumen and displace cholesterol from micelles (Armstrong \& Carey, 1987). Phytosterols contained in the blend of vegetable oils used in the present study may also explain the hypocholesterolaemic effect of diet VO100 in rainbow trout. Phytosterol levels were not measured in the diets, but rapeseed oil, the main lipid source of diet VO100 (55\%), contains around $7 \cdot 2 \mathrm{~g} / \mathrm{kg}$ phytosterols composed mainly of sitosterol, campesterol and brassicasterol, and palm oil contains $0.5 \mathrm{~g} / \mathrm{kg}$ phytosterols, mainly sitosterol, campesterol and stigmasterol (Phillips et al. 2002). It is, however, worth stating that there might be differences between species and vegetable oils used. In Atlantic salmon, replacing dietary fish oil by an oleic acid-enriched sunflower oil or palm oil, with a low content of phytosterols (about $2.6 \mathrm{~g} / \mathrm{kg}$ in sunflower oil and $0.5 \mathrm{~g}$ / $\mathrm{kg}$ in palm oil; Phillips et al. 2002), did not affect plasma or lipoprotein cholesterol levels (Torstensen et al. 2000).

LPL activity in adipose tissue was about 4-fold and 8-fold higher, respectively, than in white muscle and liver of rainbow trout in accordance with the fact that perivisceral adipose tissue and to a lesser extent white muscle are the main lipid storage tissues in rainbow trout (Corraze \& Kaushik, 1999). Although the activity of LPL in the liver was low, the present data confirm that the LPL gene is also expressed in the liver of rainbow trout as in red sea bream (Lindberg \& Olivecrona, 1995; Liang et al. 2002b). In accordance with observations in red sea bream, where hepatic LPL mRNA levels increased with dietary long-chain $n$-3 PUFA (Liang et al. 2002a), we observed a higher LPL activity and gene expression in the liver of rainbow trout fed with the fish oil diet after 44 weeks feeding. The regulation of LPL gene transcription (Michaud \& Renier, 2001) as well as post-transcriptionnal regulation (Amri et al. 1996; Michaud \& Renier, 2001) by dietary fatty acids has also been suggested in mammals. In the present study, LPL gene expression was slightly downregulated (by a factor of $1.5, P=0.046$ ) in perivisceral adipose tissue of rainbow trout fed diet VO100 compared to the FO100 group. The high level of oleic acid in the VO100 diet could explain the present results as in red sea bream LPL mRNA levels in adipose tissue were reduced with a diet supplemented with oleic acid (Liang et al. 2002a). However, the decrease in LPL gene expression seems to be really too weak to induce modification in LPL activity. The present results on tissue lipid uptake, evaluated by LPL activity, are in accordance with the absence of variation in the viscero-somatic index and muscle lipid content between the two groups of fish.

The present study showed that in rainbow trout it is possible to replace totally fish oil in diet by a blend of vegetable oils from first-feeding without compromising growth or nutrient utilization. Hepatic lipogenesis is not modified by this substitution. Dietary vegetable oils decreased circulating cholesterol and plasma LDL levels. The present results could not be related to changes in LPL and/or LDL-R expression. The mechanisms linked to the hypocholesterolaemic effect of fish oil replacement need further investigation, in particular on lipoprotein receptor number and affinity.

\section{Acknowledgements}

This work was partially supported by an INRA-IFREMER grant to the first author. This research was funded by the European Commission (FAIR no. Q5RS-2000-30 058, Researching Alternatives to Fish Oils in Aquaculture (RAFOA)) and the Aquitaine region (no. CCRRDT-2002-0308002C). We acknowledge M. Cluzeaud and E. Plagnes-Juan for technical assistance as well as technical staff at the fish farm (F. Terrier, F. Sandres and Y. Hontang).

\section{References}

Altschul SF, Gish W, Miller W, Myers EW \& Lipman DJ (1990) Basic local alignment search tool. J Mol Biol 215, 403-410.

Alvarez MJ, Diez A, Lopez-Bote C, Gallego M \& Bautista JM (2000) Short-term modulation of lipogenesis by macronutrients in rainbow trout (Oncorhynchus mykiss) hepatocytes. Br J Nutr 84, 619-628.

Amri EZ, Teboul L, Vannier C, Grimaldi PA \& Ailhaud G (1996) Fatty acids regulate the expression of lipoprotein lipase gene and activity in preadipose and adipose cells. Biochem $J$ 314, 541-546.

Armstrong MJ \& Carey MC (1987) Thermodynamic and molecular determinants of sterol solubilities in bile salt micelles. J Lipid Res 28, 1144-1155.

Babin PJ \& Vernier JM (1989) Plasma lipoproteins in fish. J Lipid Res 30, 467-489.

Baltzell JK, Wooten JT \& Otto DA (1991) Lipoprotein lipase in rats fed fish oil: apparent relationship to plasma insulin levels. Lipids 26, 289-294.

Bautista JM, Garrido-Pertierra A \& Soler G (1988) Glucose-6-phosphate dehydrogenase from Dicentrarchus labrax liver: kinetic mechanism and kinetics of NADPH inhibition. Biochim Biophys Acta 967, 354-363.

Bell JG, McEvoy J, Tocher DR, McGhee F, Campbell PJ \& Sargent JR (2001) Replacement of fish oil with rapeseed oil in diets of Atlantic salmon (Salmo salar) affects tissue lipid compositions and hepatocyte fatty acid metabolism. J Nutr 131, 1535-1543.

Bell JG, Henderson RJ, Tocher DR, McGhee F, Dick JR, Porter A, Smullen RP \& Sargent JR (2002) Substituting fish oil with crude palm oil in the diet of Atlantic salmon (Salmo salar) affects muscle fatty acid composition and hepatic fatty acid metabolism. J Nutr 132, 222-230.

Bendiksen EA, Berg OK, Jobling M, Arnesen AM \& Masoval K (2003) Digestibility, growth and nutrient utilisation of Atlantic salmon parr (Salmo salar L.) in relation to temperature, feed fat content and oil source. Aquaculture 224, 283-299.

Bengtsson-Olivecrona G \& Olivecrona T (1992) Assay of lipoprotein lipase and hepatic lipase. In Lipoprotein Analysis, pp. 169-185 [C Converse and ER Skinner, editors]. Oxford: Oxford University Press.

Blake WL \& Clarke SD (1990) Suppression of rat hepatic fatty acid synthase and S14 gene transcription by dietary polyunsaturated fat. J Nutr 120, 1727-1729. 
Bradford MM (1976) A rapid and sensitive method for the quantitation of microgram quantities of protein utilizing the principle of protein-dye binding. Anal Biochem 72, 248-254.

Caballero MJ, Obach A, Rosenlund G, Montero D, Gisvold M \& Izquierdo MS (2002) Impact of different dietary lipid sources on growth, lipid digestibility, tissue fatty acid composition and histology of rainbow trout, Oncorhynchus mykiss. Aquaculture 214, $253-271$.

Chang NW, Wu CT, Chen FN \& Huang PC (2004) High polyunsaturated and monounsaturated fatty acid to saturated fatty acid ratio increases plasma very low density lipoprotein lipids and reduces the hepatic hypertriglyceridemic effect of dietary cholesterol in rats. Nutr Res 24, 73-83.

Chapman MJ, Goldstein S, Mills GL \& Leger C (1978) Distribution and characterization of the serum lipoproteins and their apoproteins in the rainbow trout (Salmo gairdnerii). Biochemistry 17, $4455-4464$

Clarke SD, Armstrong MK \& Jump DB (1990) Dietary polyunsaturated fats uniquely suppress rat liver fatty acid synthase and S14 mRNA content. J Nutr 120, 225-231.

Corraze G \& Kaushik S (1999) Lipids from marine and freshwater fish. Oléagineux Corps Gras Lipides 6, 111-115.

Dias J, Alvarez MJ, Diez A, Arzel J, Corraze G, Bautista JM \& Kaushik SJ (1998) Regulation of hepatic lipogenesis by dietary protein/energy in juvenile European seabass (Dicentrarchus labrax). Aquaculture 161, 169-186.

Dietschy JM (1998) Dietary fatty acids and the regulation of plasma low density lipoprotein cholesterol concentrations. J Nutr 128, 444S-448S

Fernandez ML \& West KL (2005) Mechanisms by which dietary fatty acids modulate plasma lipids. J Nutr 135, 2075-2078.

Folch J, Lees M \& Sloane Stanley GH (1957) A simple method for the isolation and purification of total lipids from animal tissues. $J$ Biol Chem 226, 497-509.

Fox JC, McGill HC Jr, Carey KD \& Getz GS (1987) In vivo regulation of hepatic LDL receptor mRNA in the baboon. Differential effects of saturated and unsaturated fat. J Biol Chem 262, 7014-7020.

Gelineau A, Corraze G, Boujard T, Larroquet L \& Kaushik S (2001) Relation between dietary lipid level and voluntary feed intake, growth, nutrient gain, lipid deposition and hepatic lipogenesis in rainbow trout. Reprod Nutr Dev 41, 487-503.

Gilman CI, Leusch FDL, Breckenridge WC \& MacLatchy DL (2003) Effects of a phytosterol mixture on male fish plasma lipoprotein fractions and testis P450scc activity. Gen Comparative Endocrinol 130, $172-184$.

Gomez-Requeni P, Mingarro M, Kirchner S, Calduch-Giner JA, Medale F, Corraze G, Panserat S, Martin SAM, Houlihan DF, Kaushik SJ \& Perez-Sanchez J (2003) Effects of dietary amino acid profile on growth performance, key metabolic enzymes and somatotropic axis responsiveness of gilthead sea bream (Sparus aurata). Aquaculture 220, 749-767.

Greene DHS \& Selivonchick DP (1990) Effects of dietary vegetable, animal and marine lipids on muscle lipid and haematology of rainbow trout (Oncorhynchus mykiss). Aquaculture 89, 165-182.

Grundy SM \& Denke MA (1990) Dietary influences on serum lipids and lipoproteins. J Lipid Res 31, 1149-1172.

Guillou A, Soucy P, Khalil M \& Adambounou L (1995) Effects of dietary vegetable and marine lipid on growth, muscle fatty acid composition and organoleptic quality of flesh of brook charr (Salvelinus fontinalis). Aquaculture 136, 351-362.

Higgins DG \& Sharp PM (1989) Fast and sensitive multiple sequence alignments on a microcomputer. Comput Appl Biosci 5, 151-153.

Horton JD, Cuthbert JA \& Spady DK (1993) Dietary fatty acids regulate hepatic low density lipoprotein (LDL) transport by altering LDL receptor protein and mRNA levels. J Clin Invest 92, 743-749.
Hsu RY, Butterworth PHW \& Porter JW (1969) Pigeon liver fatty acid synthetase. In Methods of Enzymology, vol. 14, pp. 33-39 [JM Lowenstein, editor]. New York: Academic Press.

Hung SSO \& Storebakken T (1994) Carbohydrate utilization by rainbow-trout is affected by feeding strategy. J Nutr 124, 223-230.

Izquierdo MS, Obach A, Arantzamendi L, Montero D, Robaina L \& Rosenlund G (2003) Dietary lipid sources for seabream and seabass: growth performance, tissue composition and flesh quality. Aquacult Nutr 9, 397-407.

Jeffery NM, Yaqoob P, Wiggins D, Gibbons GF, Newsholme EA \& Calder PC (1996) Characterization of lipoprotein composition in rats fed different dietary lipids and of the effects of lipoproteins upon lymphocyte proliferation. J Nutr Biochem 7, 282-292.

Kuo P, Weinfeld M \& Loscalzo J (1990) Effect of membrane fatty acyl composition on LDL metabolism in Hep G2 hepatocytes. Biochemistry 29, 6626-6632.

Liang XF, Ogata HY \& Oku H (2002a) Effect of dietary fatty acids on lipoprotein lipase gene expression in the liver and visceral adipose tissue of fed and starved red sea bream Pagrus major. Comp Biochem Physiol A Mol Integr Physiol 132, 913-919.

Liang XF, Oku H \& Ogata HY (2002b) The effects of feeding condition and dietary lipid level on lipoprotein lipase gene expression in liver and visceral adipose tissue of red sea bream Pagrus major. Comp Biochem Physiol A Mol Integr Physiol 131, 335-342.

Lie O, Sandvin A \& Waagbo R (1993) Influence of dietary fatty acids on the lipid composition of lipoproteins in farmed Atlantic salmon (Salmo salar). Fish Physiol Biochem 12, 249-260.

Lin H, Romsos DR, Tack PI \& Leveille GA (1977) Influence of dietary lipid on lipogenic enzyme activities in coho salmon, Oncorhynchus kisutch (Walbaum). J Nutr 107, 846-854.

Lindberg A \& Olivecrona G (1995) Lipase evolution: trout, Xenopus and chicken have lipoprotein lipase and apolipoprotein C-II-like activity but lack hepatic lipase-like activity. Biochim Biophys Acta 1255, 205-211.

Matsuyama H, Sato K, Nakamura Y, Suzuki K \& Akiba Y (2005) Modulation of regulatory factors involved in cholesterol metabolism in response to feeding of pravastatin- or cholesterol-supplemented diet in chickens. Biochim Biophys Acta 1734, 136-142.

Matvienko OA, Lewis DS, Swanson M, Arndt B, Rainwater DL, Stewart J \& Alekel DL (2002) A single daily dose of soybean phytosterols in ground beef decreases serum total cholesterol and LDL cholesterol in young, mildly hypercholesterolemic men. Am J Clin Nutr 76, 57-64.

Menoyo D, Lopez-Bote CJ, Bautista JM \& Obach A (2003) Growth, digestibility and fatty acid utilization in large Atlantic salmon (Salmo salar) fed varying levels of n-3 and saturated fatty acids. Aquaculture 225, 295-307.

Menoyo D, Izquierdo MS, Robaina L, Gines R, Lopez-Bote CJ \& Bautista JM (2004) Adaptation of lipid metabolism, tissue composition and flesh quality in gilthead sea bream (Sparus aurata) to the replacement of dietary fish oil by linseed and soyabean oils. $\mathrm{Br} \mathrm{J}$ Nutr 92, 41-52.

Michaud SE \& Renier G (2001) Direct regulatory effect of fatty acids on macrophage lipoprotein lipase: potential role of PPARs. Diabetes 50, 660-666.

Moghadasian MH \& Frohlich JJ (1999) Effects of dietary phytosterols on cholesterol metabolism and atherosclerosis: clinical and experimental evidence. Am J Med 107, 588-594.

Montalto MB \& Bensadoun A (1993) Lipoprotein lipase synthesis and secretion: effects of concentration and type of fatty acids in adipocyte cell culture. J Lipid Res 34, 397-407.

Murphy MC, Zampelas A, Puddicombe SM, Furlonger NP, Morgan LM \& Williams CM (1993) Pretranslational regulation of the expression of the lipoprotein lipase (EC 3.1.1.34) gene by dietary fatty acids in the rat. Br J Nutr 70, 727-736.

Mustad VA, Ellsworth JL, Cooper AD, Kris-Etherton PM \& Etherton TD (1996) Dietary linoleic acid increases and palmitic acid 
decreases hepatic LDL receptor protein and mRNA abundance in young pigs. J Lipid Res 37, 2310-2323.

National Research Council (1993) Nutrient Requirements of Fish. Washington, DC: National Academy Press.

New MB \& Wijkstroem UN (2002) Use of Fishmeal and Fish Oil in Aquafeeds. Futher Thoughts on the Fishmeal Trap. FAO Fisheries Circular no. 975. Rome: FAO.

Normen L, Dutta P, Lia A \& Andersson H (2000) Soy sterol esters and beta-sitostanol ester as inhibitors of cholesterol absorption in human small bowel. Am J Clin Nutr 71, 908-913.

Ochoa S (1955) Malic enzyme. In Methods of Enzymology, vol. 11, pp. 739-753 [SP Colowick and NO Kaplan, editors]. New York: Academic Press.

Pfaffl MW, Horgan GW \& Dempfle L (2002) Relative expression software tool (REST (C)) for group-wise comparison and statistical analysis of relative expression results in real-time PCR. Nucleic Acids Res 30, 1-10.

Phillips KM, Ruggio DM, Toivo JI, Swank MA \& Simpkins AH (2002) Free and esterified sterol composition of edible oils and fats. J Food Compost Anal 15, 123-142.

Raclot T, Groscolas R, Langin D \& Ferre P (1997) Site-specific regulation of gene expression by $\mathrm{n}-3$ polyunsaturated fatty acids in rat white adipose tissues. J Lipid Res 38, 1963-1972.

Regost C, Arzel J, Cardinal M, Robin J, Laroche M \& Kaushik SJ (2001) Dietary lipid level, hepatic lipogenesis and flesh quality in turbot (Psetta maxima). Aquaculture 193, 291-309.

Regost C, Arzel J, Robin J, Rosenlund G \& Kaushik SJ (2003) Total replacement of fish oil by soybean or linseed oil with a return to fish oil in turbot (Psetta maxima) -1. Growth performance, flesh fatty acid profile, and lipid metabolism. Aquaculture 217, 465-482.

Rosenlund G, Obach A, Sandberg MG, Standal H \& Tveit K (2001) Effect of alternative lipid sources on long-term growth performance and quality of Atlantic salmon (Salmo salar L.). Aquacult Res 32, 323-328.

Salati LM \& Amir-Ahmady B (2001) Dietary regulation of expression of glucose-6-phosphate dehydrogenase. Anпи Rev Nutr 21, 121-140.

Salter AM, Mangiapane EH, Bennett AJ, Bruce JS, Billett MA, Anderton KL, Marenah CB, Lawson N \& White DA (1998) The effect of different dietary fatty acids on lipoprotein metabolism: concentration-dependent effects of diets enriched in oleic, myristic, palmitic and stearic acids. Br J Nutr 79, 195-202.

Shantha NC \& Ackman RG (1990) Nervonic acid versus tricosanoic acid as internal standards in quantitative gas chromatographic analyses of fish oil longer-chain n-3 polyunsaturated fatty acid methyl esters. J Chromatogr B Biomed Appl 533, 1-10.
Sheridan MA (1988) Lipid dynamics in fish: aspects of absorption, transportation, deposition and mobilization. Comp Biochem Physiol B Biochem Mol Biol 90, 679-690.

Sorci-Thomas M, Wilson MD, Johnson FL, Williams DL \& Rudel LL (1989) Studies on the expression of genes encoding apolipoproteins B100 and B48 and the low density lipoprotein receptor in nonhuman primates. Comparison of dietary fat and cholesterol. J Biol Chem 264, 9039-9045.

Spady DK \& Dietschy JM (1988) Interaction of dietary cholesterol and triglycerides in the regulation of hepatic low density lipoprotein transport in the hamster. J Clin Invest 81, 300-309.

Stabile LP, Hodge DL, Klautky SA \& Salati LM (1996) Posttranscriptional regulation of glucose-6-phosphate dehydrogenase by dietary polyunsaturated fat. Arch Biochem Biophys 332, 269-279.

Stabile LP, Klautky SA, Minor SM \& Salati LM (1998) Polyunsaturated fatty acids inhibit the expression of the glucose-6-phosphate dehydrogenase gene in primary rat hepatocytes by a nuclear posttranscriptional mechanism. $J$ Lipid Res 39, 1951-1963.

Temme EHM, Mensink RP \& Hornstra G (1997) Effects of medium chain fatty acids (MCFA), myristic acid, and oleic acid on serum lipoproteins in healthy subjects. J Lipid Res 38, 1746-1754.

Tocher DR (2003) Metabolism and functions of lipids and fatty acids in teleost fish. Fish Sci 11, 107-184.

Torstensen BE, Lie O \& Froyland L (2000) Lipid metabolism and tissue composition in Atlantic salmon (Salmo salar L.) - effects of capelin oil, palm oil, and oleic acid-enriched sunflower oil as dietary lipid sources. Lipids 35, 653-664.

Torstensen BE, Froyland L \& Lie O (2004) Replacing dietary fish oil with increasing levels of rapeseed oil and olive oil - effects on Atlantic salmon (Salmo salar L.) tissue and lipoprotein lipid composition and lipogenic enzyme activities. Aquacult Nutr 10, 175-192.

Vanstone CA, Raeini-Sarjaz M, Parsons WE \& Jones PJ (2002) Unesterified plant sterols and stanols lower LDL-cholesterol concentrations equivalently in hypercholesterolemic persons. Am J Clin Nutr 76, 1272-1278.

Walzem RL, Storebakken T, Hung SS \& Hansen RJ (1991) Relationship between growth and selected liver enzyme activities of individual rainbow trout. J Nutr 121, 1090-1098.

Watanabe T (1982) Lipid nutrition in fish. Comp Biochem Physiol B Biochem Mol Biol 273, 3-15.

Zampelas A, Murphy M, Morgan LM \& Williams CM (1994) Postprandial lipoprotein lipase, insulin and gastric inhibitory polypeptide responses to test meals of different fatty acid composition: comparison of saturated, n- 6 and n-3 polyunsaturated fatty acids. Eur J Clin Nutr 48, 849-858. 